\title{
SPATIALLY SCALED RESPONSE OF A LAZULI BUNTING POPULATION TO FIRE
}

\author{
Author(s): Andreas Leidolf, Tim Nuttle, Michael L. Wolfe
}

Source: Western North American Naturalist, 67(1):1-7. 2007.

Published By: Monte L. Bean Life Science Museum, Brigham Young University

DOI: http://dx.doi.org/10.3398/1527-0904(2007)67[1:SSROAL]2.0.CO;2

URL: http://www.bioone.org/doi/

full/10.3398/1527-0904\%282007\%2967\%5B1\%3ASSROAL\%5D2.0.CO\%3B2

BioOne (www.bioone.org) is a nonprofit, online aggregation of core research in the biological, ecological, and environmental sciences. BioOne provides a sustainable online platform for over 170 journals and books published by nonprofit societies, associations, museums, institutions, and presses.

Your use of this PDF, the BioOne Web site, and all posted and associated content indicates your acceptance of BioOne's Terms of Use, available at www.bioone.org/page/ terms of use.

Usage of BioOne content is strictly limited to personal, educational, and non-commercial use. Commercial inquiries or rights and permissions requests should be directed to the individual publisher as copyright holder. 


\title{
SPATIALLY SCALED RESPONSE OF A LAZULI BUNTING POPULATION TO FIRE
}

\author{
Andreas Leidolf ${ }^{1,2}$, Tim Nuttle ${ }^{3,4}$, and Michael L. Wolfe ${ }^{1}$
}

\begin{abstract}
Aвstract-We examined the response of Lazuli Bunting (Passerina amoena) to fire in Gambel oak (Quercus gambelii) woodland at Camp Williams, Utah, during 1993-1998. Overall, Lazuli Bunting abundance on the study area increased significantly during the 2 years after a stand-replacing wildfire, which covered 800 ha of Gambel oak woodland. This increase suggested that Lazuli Buntings respond positively to fire. However, a comparison of pre- and postfire abundance of Lazuli Bunting for 2 groups of monitoring plots with different fire histories showed that abundance was significantly greater during the post-fire period for both burned and unburned plots. When we examined our data at a spatial scale appropriate to Lazuli Bunting, we found that post-fire increases observed on unburned plots were limited to plots in close proximity to the burned area. A comparison of pre- and post-fire abundance of Lazuli Bunting for 3 groups of monitoring plots located at various distances from the burned area revealed that post-fire abundance was similar only for plots within the fire boundary and for those $\leq 1000 \mathrm{~m}$ from the fire boundary; plots located $>1000 \mathrm{~m}$ from the fire boundary had fewer individuals per plot post-fire. However, prefire Lazuli Bunting abundance was similar among all 3 categories. This differential, spatially scaled response of Lazuli Bunting to fire at the landscape level may support a hierarchical view of habitat selection.
\end{abstract}

Key words: Lazuli Bunting, Passerina amoena, disturbance, Gambel oak woodland, Quercus gambelii, bird populations, population monitoring, spatial scale, Utah.

Johnson (1980) hypothesized that animals select habitat hierarchically at various spatial scales, beginning with selection of a broad geographic range (1st-order selection), followed by selection of a home range (2nd-order selection) and selection and use of individual habitat components within that home range (3rd-order selection) to meet specific life requisites, for example, nesting or foraging sites. In recent years, several studies have provided experimental and observational evidence supporting this hypothesis with respect to habitat choice by birds (e.g., Orians and Wittenberger 1991, Bergin 1992, Steele 1992).

If habitat selection by birds is hierarchical and spatially scaled, one would expect an equally scaled avian response to ecological processes that impact and alter habitats, for example, large-scale disturbance. Directly demonstrating such a response generally requires careful experimentation employing such common standards of good experimental design as replication, randomization, and local control (e.g., Steele 1992). Unfortunately, such habitat manipulations are difficult and frequently unethical at large spatial scales and, even when feasible, they may not adequately represent such significant ecological events as natural disturbances. It is not surprising, then, that experimental investigations of hierarchical habitat selection to date have been limited primarily to phenomena occurring at small spatial scales.

Here we offer an alternative approach, relying on induction rather than on more traditional hypothetico-deductive reasoning, to address large-scale phenomena in the context of hierarchical habitat selection. Specifically, we show how a spatially explicit analysis can be used to reveal an organism's differential (and thus spatially scaled) response to habitat at successively finer spatial scales. Whether such a differential response can be used to infer a hierarchically structured decision-making process is left to the reader's judgment. Nevertheless we offer this approach as a valuable tool for data exploration and hypothesis formulation in the study of habitat selection as related to large-scale natural disturbance.

\footnotetext{
${ }^{1}$ Department of Wildland Resources and Ecology Center, Utah State University, Logan, UT 84322-5230.

${ }^{2}$ Present address: Department of Biology, Chemistry and Environmental Science, Westminster College, 501 Westminster Avenue, Fulton, MO $65251-1299$. E-mail: leidola@westminster-mo.edu

${ }^{3}$ Department of Biology and Ecology Center, Utah State University, Logan, UT 84322-5305.

${ }^{4}$ Present address: Department of Biological Sciences, University of Pittsburgh, Pittsburgh, PA 15260.
} 
Our analysis centers on Lazuli Bunting (Passerina amoena) response to a stand-replacing wildfire that occurred at Camp W.G. Williams State Military Reservation, a Utah Army National Guard (UTARNG) training facility, in 1995. This fire burned over 800 ha of Gambel oak (Quercus gambelii) woodland over several days, killing all aboveground vegetation and removing all aboveground biomass excepting large stems.

For this investigation, we considered the Lazuli Bunting an ideal study organism for several reasons. First, Lazuli Buntings respond positively to fire (Hutto 1995, Greene et al. 1996). Second, they are sexually dimorphic, with males being particularly colorful and noticeable. Males are also highly territorial and vocal, singing loudly from exposed perches at the top of the canopy throughout the breeding season (Greene et al. 1996). Because of these life history attributes, we were confident that observer bias, as well as bias due to differential detectability between burned and unburned habitat, would be minimal. Finally, because Lazuli Buntings are active singers throughout the breeding season (Greene et al. 1996), we had a relatively long window of time for field work.

\section{STUDY SITE}

Camp Williams $\left(40^{\circ} 26^{\prime} \mathrm{N}, 112^{\circ} 0^{\prime} \mathrm{W}\right)$ is located in north central Utah, approximately $47 \mathrm{~km}$ southwest of Salt Lake City. The site covers ca. 10,125 ha in Salt Lake and Utah Counties, and is bordered by the Jordan River to the east and the Oquirrh Mountains to the west. The Traverse Mountains, which Camp Williams straddles, range in elevation from 1281 to $2196 \mathrm{~m}$ and form a natural bridge between the Oquirrh Mountains to the west and the Wasatch Mountains to the east (Fig. 1).

Camp Williams is in the Basin and Range floristic province, bounded by the Great Basin Desert to the west and the Colorado Plateau to the east. Dominant vegetation types include sagebrush-grass shrubland (35.4\%), Gambel oak woodland $(28.5 \%)$, and pinyon-juniper woodland $(6.3 \%)$. Military training exercises were the dominant land use on Camp Williams; during this study, military use averaged 400,000 troop-training days per year (UTARNG Camp W.G. Williams Range Control unpublished data). Other land uses included moderate cattle and sheep grazing.
A detailed description of the fire history of Camp Williams was provided by Godfrey (1995). Like elsewhere across much of Gambel oak range (Wadleigh et al. 1998), increased ignition frequency associated with greater human activity has resulted in a decreased fire-return interval in Gambel oak woodland at Camp Williams. Although both small- and intermediately sized fires are frequent occurrences elsewhere at Camp Williams, the area considered here had not burned in $>60$ years prior to the 1995 fire (Godfrey 1995).

\section{Methods}

We monitored Lazuli Bunting abundance in Gambel oak woodland in conjunction with an avian community monitoring program at Camp Williams during 1993 and 1995 (prefire) and 1997 and 1998 (post-fire) by using 67 permanent 50-m-radius (0.785-ha) circular plots and generally following standards recommended by Ralph et al. $(1993,1995)$. Of the 67 plots, 33 were located within the 1995 fire boundary, and 34 were located outside the boundary (Fig. 1). However, all plots were comparable with respect to topography (mostly moderately steep slopes), aspect (mostly northfacing), and elevation ( $\bar{x}=1799.8 \mathrm{~m}, s=115.5$ $\mathrm{m})$, and they supported identical vegetation communities (almost exclusively Gambel oak). The same plots were visited once each year. Plots were established along transects (8-14 plots per transect) at $200-\mathrm{m}$ intervals from a random starting point. Counts were conducted from 1 May through 31 July. Counts typically began at 0600 hours (MST) and were completed by 1030 hours. We did not census in rainy or extremely windy conditions. One or 2 observers were used each year, but only $1 \mathrm{ob}-$ server censused birds on a given plot in any given year; furthermore, survey assignments were made without preconceived bias, and plots monitored by the same observer were spatially interspersed such that each observer surveyed plots in both burned and unburned habitat in any given year. Counts began immediately when an observer reached a plot and continued for 5 minutes; data were subtallied by minute. Individuals flushed within $50 \mathrm{~m}$ of plot center as the observer approached or left the plot were counted as being inside the plot. We recorded all birds seen or heard, but considered only singing males in our analysis. All 


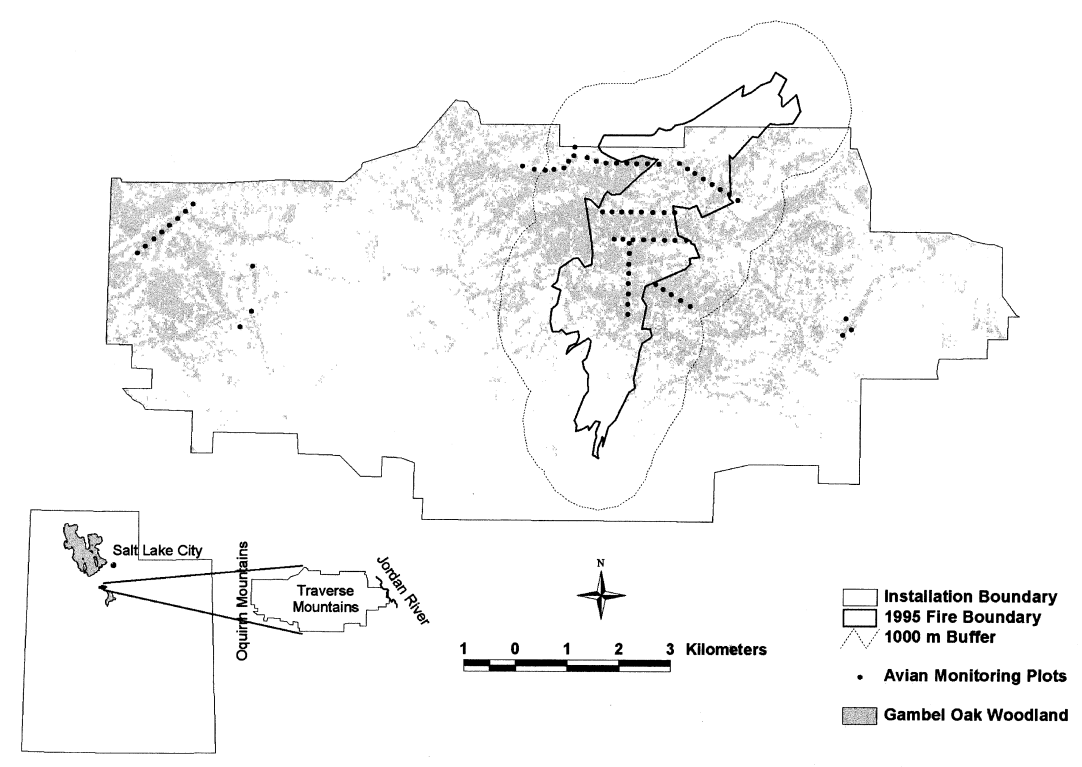

Fig. 1. Map of study area, Camp W.G. Williams State Military Reservation, Utah, showing distribution of Gambel oak woodland, 1995 fire boundary, distance categories, and location of avian monitoring plots.

observers were trained to identify Lazuli Buntings by sight and sound. In addition, each observer was trained in distance estimation in Gambel oak woodland using known distances and a range finder. Nevertheless, distances to birds perceived to be at or near the plot boundary were verified by pacing. Distance calibration was performed annually and for each new observer.

We compared Lazuli Bunting abundance among years with a general linear mixed model of a 1-way factorial in a randomized block design where plots were blocks. As appropriate $(P<0.050)$, we used Tukey's Studentized Range Test to separate means while controlling Type I experimental error (Day and Quinn 1989). We compared pre- and post-fire Lazuli Bunting abundance on burned and unburned plots using a general linear mixed model of a 2-way factorial in a split-plot design, with fire history (burned or unburned) as the wholeplot factor and period (pre- and post-fire) as the split-plot factor; data values were averaged over the 2 years in each period.

We then divided monitoring plots into 3 distance categories based on their location with respect to the 1995 fire boundary: plots located within the fire boundary $(n=33)$, plots $\leq 1000 \mathrm{~m}$ from the fire boundary $(n=$
18), and plots $>1000 \mathrm{~m}$ from the fire boundary $(n=16$; Fig. 1). Our a priori selection of 1000 $\mathrm{m}$ as a breakpoint was based on 2 criteria. First, because monitoring plots were preestablished, we had to select a breakpoint that would allow for a sufficient number of monitoring plots in each category to make statistical comparisons. A breakpoint of $1000 \mathrm{~m}$ provided a sufficient sample size for all 3 categories. Second, we wanted to select an observational scale appropriate for the organism. Although Lazuli Bunting territory size in Gambel oak woodland is unknown, we used known ranges of Lazuli Bunting territory size in other habitats (0.5-6 ha) as a reference (Greene et al. 1996). Based on our observations since completing this study, we suggest that Lazuli Bunting territories at Camp Williams fall well within that range, with most territories not exceeding 3 ha in size (Leidolf and Wolfe unpublished data). Thus, a distance of $1000 \mathrm{~m}$ was both ecologically meaningful for this species and minimized confounding due to territories that overlapped the fire boundary. We compared mean abundance of Lazuli Bunting among distance categories and between pre- and post-fire periods using a general linear mixed model of a 2-way factorial in a splitplot design with distance category as the 
whole-plot factor and period as the split-plot factor. All computations were performed in SAS, release 6.12, using the procedure MIXED (Littell et al. 1996).

\section{Results}

Mean abundance of Lazuli Bunting differed significantly among years $(P=0.001$, $\left.F_{3,175}=5.46\right)$. Mean abundance was significantly higher in 1998 (0.36 \pm 0.06 individuals per plot) than in $1993(0.11 \pm 0.08$ individuals per plot) or 1995 (0.04 \pm 0.06 individuals per plot), but did not differ significantly from mean abundance in 1997 (0.24 \pm 0.06 individuals per plot). Mean abundance in 1997 was greater than in 1993 and 1995, but not significantly so.

Mean abundance of Lazuli Bunting on burned plots was higher during the post-fire period $(0.33 \pm 0.06$ individuals per plot $)$ than during the prefire period $(0.09 \pm 0.06$ individuals per plot; Fig. 2). On unburned plots, mean abundance was also higher during the post-fire period $(0.25 \pm 0.06$ individuals per plot) compared to the prefire period $(0.03 \pm$ 0.06 individuals per plot; Fig. 2). The interaction term, fire history $\times$ period, was not significant $\left(P=0.854, F_{1,65}=0.03\right)$, indicating no significant difference between burned and unburned plots in the change in mean abundance of Lazuli Bunting from the pre- to the post-fire period. Subsequent examination of the main effects showed that, whereas the difference in mean abundance between burned and unburned plots was not significant $(P=$ $\left.0.279, F_{1,65}=1.19\right)$, the difference in mean abundance between the pre- and post-fire period was highly significant $\left(P \leq 0.001, F_{1,65}\right.$ $=15.40$ ).

Our analysis revealed a significant $(P=$ $\left.0.0375, F_{2,64}=3.46\right)$ interaction of distance category by period, indicating that differences in mean abundance of Lazuli Bunting among distance categories differed significantly between the pre- and post-fire period. Mean abundance of Lazuli Bunting during the prefire period was greatest on plots within the 1995 fire boundary $(0.09 \pm 0.06$ individuals per plot) and was slightly lower on plots located $\leq 1000 \mathrm{~m}$ from the fire boundary $(0.03$ \pm 0.08 individuals per plot) and plots located at distances $>1000 \mathrm{~m}$ from the fire boundary $(0.03 \pm 0.9$ individuals per plot; Fig. $3 \mathrm{~A})$. Dur-

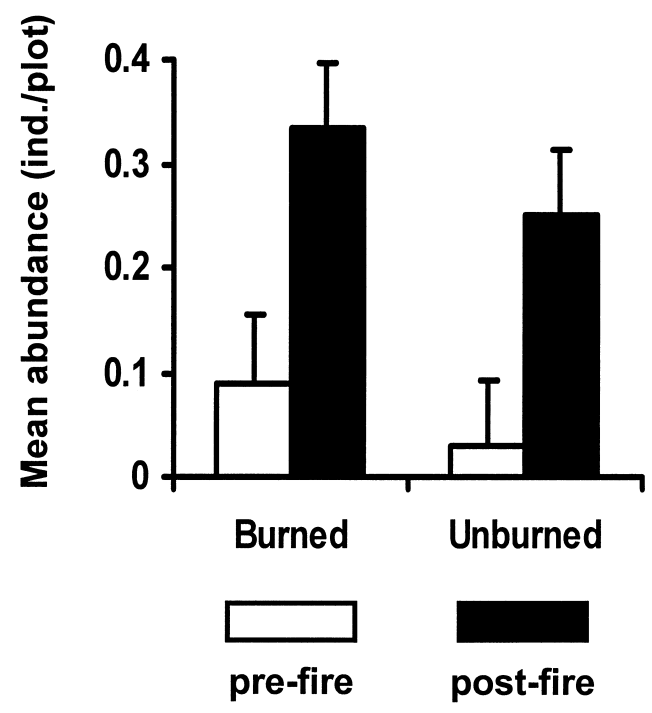

Fig. 2. Mean abundance (individuals per plot) of Lazuli Bunting on burned and unburned plots before (prefire) and after (post-fire) stand-replacing wildfire in Gambel oak woodland at Camp W.G. Williams State Military Reservation, Utah, 1993-1998.

ing the post-fire period, mean abundance was highest on plots located $\leq 1000 \mathrm{~m}$ from the fire boundary $(0.44 \pm 0.08$ individuals per plot), followed by plots within the fire boundary $(0.33 \pm 0.06$ individuals per plot); mean abundance on plots $>1000 \mathrm{~m}$ from the fire boundary was lower by an order of magnitude $(0.03$ \pm 0.09 individuals per plot; Fig. 3B).

\section{Discussion}

Although Lazuli Buntings are known to breed in a wide range of shrubland habitats, highest breeding densities have been reported from recent post-fire habitats (Hutto 1995, Greene et al. 1996). In Gambel oak woodland at Camp Williams, Lazuli Buntings were more abundant in the 2 and 3 years post-fire than in the 2 years prefire. However, significant increases in abundance were observed post-fire on burned and unburned plots (Fig. 2). Thus, perhaps Lazuli Buntings were experiencing a regional population increase during the postfire years of 1997 and 1998. This explanation, however, is not supported by regional Lazuli Bunting population trends for the Basin and Range physiographic province and the state of Utah, based on Breeding Bird Survey (BBS) data (Sauer et al. 1999; Fig. 4). A trend analysis 
(A) Pre-fire

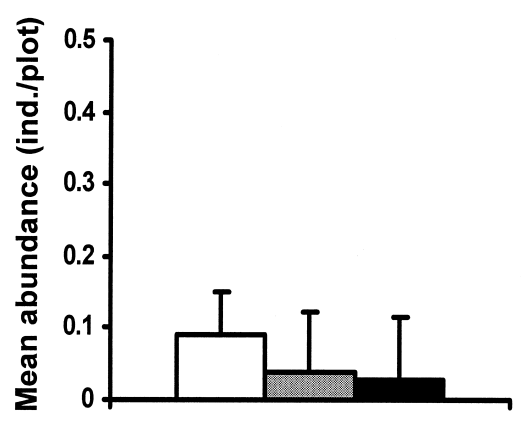

(B) Post-fire

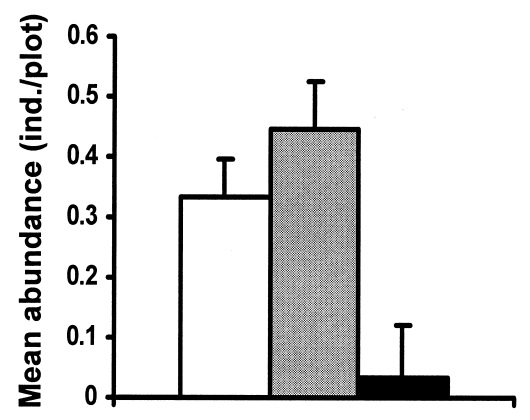

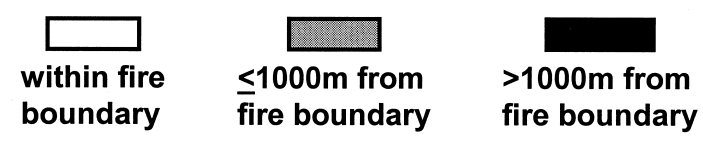

Fig. 3. Mean abundance (individuals per plot) of Lazuli Bunting on plots in 3 distance categories (within the fire boundary, $\leq 1000 \mathrm{~m}$ from the fire boundary, >1000 $\mathrm{m}$ from the fire boundary) before (prefire, A) and after (post-fire, B) stand-replacing wildfire in Gambel oak woodland at Camp W.G. Williams State Military Reservation, Utah, 1993-1998.

of BBS data using a linear route-regression approach based on estimating equations (Sauer et al. 1999) showed no significant trend for either region $(P=0.518$ and 0.736 , respectively), although others have suggested that Lazuli Bunting populations in Utah may actually be declining (DeSante and George 1994). An alternative explanation to a regional population increase, however, is that Lazuli Bunting populations in both burned and unburned plots at Camp Williams may have responded positively to fire. This 2 nd hypothesis is supported by our comparison of Lazuli Bunting abundance among plots in 3 distance categories (Fig. 3).

Two conclusions may be drawn. First, Lazuli Buntings at Camp Williams responded positively to fire. Given the obvious lack of replication and interspersion inherent to a study of large-scale natural disturbance such as ours, this conclusion is derived less from statistical inference than from ecological inference (Hawkins 1986). To wit, the observed differences among statistical populations (i.e., preand post-fire, burned and unburned, etc.) are real; the role of fire vis-à-vis these observed differences can be inferred from the lack of other obvious explanations combined with published reports of Lazuli Buntings rapidly colonizing recent burns in large numbers

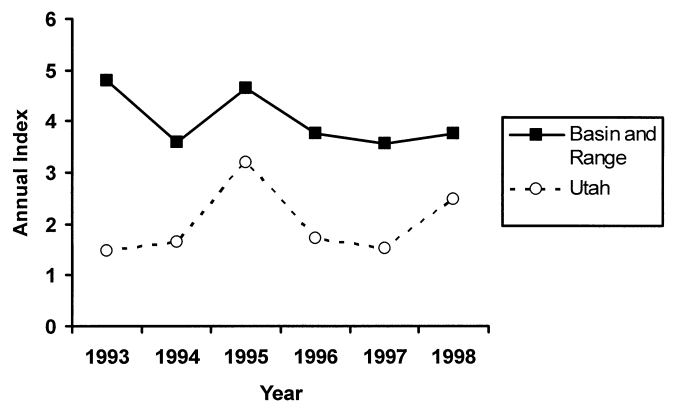

Fig. 4. Population trend of Lazuli Bunting during 19931998 for the Basin and Range physiographic province and the state of Utah based on USGS Breeding Bird Survey data (redrawn from Sauer et al. 1999). Population trends for this time period were not significant in a separate trend analysis using a linear route-regression approach based on estimating equations (Sauer et al. 1999).

(Hutto 1995, Greene et al. 1996). Second, the observed response occurred at a larger scale than the burn itself, but at a smaller scale than that of the local population (i.e., Camp Williams). This differential, spatially scaled response may suggest a hierarchically structured decision process regarding habitat selection as envisioned by Johnson (1980). 
If recent post-fire habitats are preferred by Lazuli Bunting, and if their habitat selection is indeed hierarchically structured, individuals would make an ordered set of decisions regarding habitat choice. After the general geographic area is selected (e.g., the Traverse Mountains), one would expect 2nd-order selection favoring landscapes that feature recently burned areas, resulting in an increase in Lazuli Bunting abundance in these areas. The behavioral plasticity necessary for such a response, including low natal philopatry of returning juveniles and the ability of adults to disperse among suitable breeding habitats among years, is well documented (Greene et al. 1996). Next, selection of habitat components at the scale of an individual's territory may focus initially on the preferred burned habitat, with earlier-arriving migrants occupying these areas first. As individuals continue to arrive during migration, availability of territories in the preferred habitat declines, forcing later-arriving individuals to select less preferred, but suitable habitats in the surrounding landscape. In this context, it would be interesting to learn whether individuals censused in the area surrounding the burn were singing, nonbreeding individuals that were attracted to the burned area but could not establish territories there (see Van Horne 1983). With increasing distance from the burned area, the influence of the burn on Lazuli Bunting response would diminish. This hierarchically structured process should result in an increase in Lazuli Bunting abundance in both burned habitats and those immediately adjacent to them, but not in areas at greater distances from burned habitat, similar to the observations made in this study.

Hierarchical habitat selection has been documented for a number of bird species, including Western Kingbird (Tyrannus verticalis; Bergin 1992), Black-throated Blue Warbler (Dendroica caerulescens; Steele 1992), and Yellow-headed Blackbird (Xanthocephalus xanthocephalus; Orians and Wittenberger 1991). In these studies the causal mechanisms evoking the habitat selection response were identified or strongly suggested. However, possible explanations for a preference by Lazuli Bunting towards recent post-fire habitats are elusive, and our argument is therefore tentative. Presence of recent post-fire habitat or edge between burned and unburned habitat created by fire may be a proximate cue used by Lazuli Bunting in making settling decisions. Once settling has occurred, however, nest sites and territories may be selected based on entirely different parameters, which may be only loosely correlated with fire. For example, Orians and Wittenberger (1991) reported that Yellow-headed Blackbirds used the emergence rate of odonate insects as a criterion in making settling decisions, but selected nest sites based on vegetation density. Possible explanations of Lazuli Bunting preference for burned areas include a lowered risk of Brown-headed Cowbird (Molothrus ater) parasitism, to which Lazuli Buntings may be more susceptible than previously thought (Greene 1999, but see Friedmann 1929, Friedmann et al. 1977, Friedmann and Kiff 1985). For example, Greene et al. (1999) found that the only extensive Lazuli Bunting habitats predicted to present no risk of Brown-headed Cowbird parasitism were recently burned areas. There is anecdotal evidence that Brown-headed Cowbird abundance at Camp Williams may be lower in recent burns than in adjacent unburned habitat (Leidolf and Wolfe unpublished data), but further research is needed to more firmly establish this correlation.

Clearly, much is left to learn regarding the complexity of decision-making relative to habitat choice by Lazuli Buntings. The evidence suggesting hierarchically structured habitat selection in birds is considerable (e.g., James 1971, Wiens and Rotenberry 1981, Wiens et al. 1987, Orians and Wittenberger 1991, Bergin 1992, Steele 1992). Nonetheless, the specifics of hierarchically based habitat selection in response to large-scale phenomena will take a concerted effort to unravel. To this end, our investigation poses more questions than it answers, and further research is warranted on abundance, productivity, nest site selection, and territory size of Lazuli Bunting, with particular emphasis on the ecological importance of post-burn areas for Lazuli Bunting reproduction (Greene et al. 1999).

The response of Lazuli Bunting to fire reported here is local in nature and cannot readily be extrapolated given the limited inferential space typically associated with studies of large-scale natural disturbance. Nevertheless, our investigation has shown that we may need to think differently about local habitat 
selection in the context of a presumed hierarchy. With respect to large-scale disturbance, it may be advantageous to routinely consider multiple spatial scales simultaneously: the spatial scale of the disturbance and the scale associated with the affected organism.

\section{ACKNOWLEDGMENTS}

We thank field assistants C.B. Hendrix, P. Meyers, and M.C. Reynolds. D.A. Johnson and Lieutenant Colonel R.T. Dunton provided logistic support during field work. T.G. van Niel and K. Bartsch generated maps of the study area and provided GIS and mapping support. We are grateful to S. Durham for her assistance during data analysis. Finally, we thank S. Durham, J. Ostermiller, and Drs. M.A. Baker, J.A. Bissonette, R.T. Engstrom, E. Greene, J.W. Haefner, and B.B. Steele for providing helpful comments on earlier versions of the manuscript, and we thank 2 anonymous referees for review of the final draft. Nuttle was supported by a Utah State University (USU) College of Science / Willard Eccles Fellowship. Leidolf was supported by a UTARNG grant, a USU Ecology Center Fellowship and Stipend, and by the USGS Utah Cooperative Fish and Wildlife Research Unit.

\section{Literature Cited}

Bergin, T.M. 1992. Habitat selection by the Western Kingbird in western Nebraska: a hierarchical analysis. Condor 94:903-911.

DaY, R.W., AND G.P. Quinn. 1989. Comparison of treatments after an analysis of variance in ecology. Ecological Monographs 59:433-463.

DeSante, D.F., and T.L. George. 1994. Population trends in the landbirds of western North America. Studies in Avian Biology 15:173-190.

FriedmanN, H. 1929. The cowbirds: a study in the biology of social parasitism. Thomas, Springfield, IL.

FriedmanN, H., AND L.F. KIFF. 1985. The parasitic cowbirds and their hosts. Proceedings of the Western Foundation of Vertebrate Zoology 2:226-304.

Friedmann, H., L.F. Kiff, and S.I. Rothstein. 1977. A further contribution to the knowledge of the host relations of the parasitic cowbirds. Smithsonian Contributions in Zoology 235:1-75.

Godfrey, J.E. 1995. Fire occurrence and behavior and the effect of fire on deer mouse density in oakbrush on Camp Williams National Guard Base, Utah. Master's thesis, Utah State University, Logan.

Greene, E. 1999. Demographic consequences of Brownheaded Cowbird parasitization of Lazuli Buntings. Studies in Avian Biology 18:144-152.

Greene, E., J. Jolivette, And R. Redmond. 1999. Lazuli Buntings and Brown-headed Cowbirds in Montana: a state-wide landscape analysis of potential sources and sinks. Studies in Avian Biology 18:135-143.

Greene, E., V.R. Muehter, And W. Davison. 1996. Lazuli Bunting (Passerina amoena). In A. Poole and F. Gill, editors, The birds of North America, no. 232. Academy of Natural Sciences, Philadelphia, PA, and American Ornithologists' Union, Washington, DC.

Hawkins, C.P. 1986. Pseudo-understanding of pseudoreplication: a cautionary note. Bulletin of the Ecological Society of America 67:184-185.

HutTo, R.L. 1995. Composition of bird communities following stand-replacement fires in Northern Rocky Mountain (USA) conifer forests. Conservation Biology 9:1041-1058.

JAMES, F.C. 1971. Ordination of habitat relationships among breeding birds. Wilson Bulletin 83:215-236.

Johnson, D.H. 1980. The comparison of usage and availability measurements for evaluating resource preference. Ecology 61:65-71.

Littell, R.C., G.A. Milliken, W.W. Stroup, and R.D. WOLFINGER. 1996. SAS system for mixed models. SAS Institute, Inc., Cary, NC.

Orians, G.H., And J.F. Wittenberger. 1991. Spatial and temporal scales in habitat selection. American Naturalist 137(supplement):29-49.

Ralph, C.J., G.R. Geupel, P. Pyle, T.E. Martin, and D.F. DESANTE. 1993. Handbook of field methods for monitoring landbirds. General Technical Report PSW-144, USDA Forest Service, Pacific Southwest Research Station, Albany, CA.

Ralph, C.J., J.R. Sauer, and S. Droege. 1995. Managing and monitoring birds using point counts: standards and applications. Pages 161-175 in C.J. Ralph, J.R. Sauer, and S. Droege, editors, Monitoring bird populations by point counts. General Technical Report PSW-149, USDA Forest Service, Pacific Southwest Research Station, Albany, CA.

Sauer, J.R., J.E. Hines, I. Thomas, J. Fallon, and G. Gough. 1999. The North American Breeding Bird Survey, results and analysis 1966-1998. Version 98.1. USDI Geological Survey, Patuxent Wildlife Research Center, Laurel, MD.

SteEle, B.B. 1992. Habitat selection by breeding Blackthroated Blue Warblers at two spatial scales. Ornis Scandinavica 23:33-42.

VAN Horne, B. 1983. Density as a misleading indicator of habitat quality. Journal of Wildlife Management 47: 893-901.

Wadleigh, L.L., C. Parker, and B. Smith. 1998. A fire frequency and comparative fuel load analysis in Gambel oak of northern Utah. Proceedings of the Tall Timbers Fire Ecology Conference 20:267-272.

Wiens, J., AND J.T. Rotenberry. 1981. Habitat associations and community structure of birds in shrubsteppe environments. Ecological Monographs 51: $21-41$.

Wiens, J., J.T. Rotenberky, and B.A. Van Horne. 1987. Habitat occupancy patterns of North American shrubsteppe birds: the effects of spatial scale. Oikos 48: 132-147.

Received 6 December 2005 Accepted 2 August 2006 